\title{
Mechanization Status, Promotional Activities and Government Strategies of Thailand and Vietnam in Comparison to Bangladesh
}

\author{
Md. Anwar Hossen ${ }^{1, *}$, Md. Ruhul Amin Talukder ${ }^{2}$, Muhammad Rashed Al Mamun ${ }^{3}$, \\ Hafijur Rahaman ${ }^{4}$, Subrata Paul ${ }^{1}$, Md. Mizanur Rahman ${ }^{1}$, Md. Miaruddin ${ }^{5}$, Md. Azhar Ali ${ }^{6}$ \\ and Md. Nurul Islam ${ }^{6}$ \\ 1 Farm Machinery and Postharvest Technology Division, Bangladesh Rice Research Institute (BRRI), \\ Gazipur 1701, Bangladesh; engr.subrata_paul@hotmail.com (S.P.); mizanbau@gmail.com (M.M.R.) \\ 2 Ministry of Agriculture, Dhaka 1215, Bangladesh; ruhul42@gmail.com \\ 3 Department of Farm Power and Machinery, Faculty of Agricultural Engineering and Technology, \\ Sylhet Agricultural University, Sylhet 3100, Bangladesh; rashed.fpm@sau.ac.bd \\ 4 Workshop Machinery and Maintenance Division, BRRI, Gazipur 1701, Bangladesh; \\ overahman14@gmail.com \\ 5 Bangladesh Agricultural Research Institute (BARI), Gazipur-1701, Bangladesh; miar303@yahoo.com \\ 6 Department of Agricultural Extension, Dhaka 1215, Bangladesh; a.azhar.kh@gmail.com (M.A.A.); \\ nurul7699@yahoo.com (M.N.I.) \\ * Correspondence: ahossenbrri@gmail.com
}

Received: 27 July 2020; Accepted: 19 September 2020; Published: 23 September 2020

check for updates

\begin{abstract}
Reasonable use of agricultural machinery has an extraordinary potential for poverty alleviation by increasing land and labor productivity in Thailand, Vietnam, and even in Bangladesh. This study was conducted under a program entitled "Agriculture Mechanization, Agro-Processing, Value addition and Export Market Development in Thailand and Vietnam from 1-14 November, 20I9" from the Ministry of Agriculture, Bangladesh. In all three distinct nations, farming activities represent a significant area of activity and remains the biggest wellspring of agricultural business. About $10.5 \%$ of Thailand's, $21.5 \%$ of Vietnam's, and $14.23 \%$ of Bangladesh's GDP come from agriculture. For sustainable development, it is essential to modernize agriculture through the mechanization of its operations, which is therefore inevitable in the studied countries. Thailand's government started mechanization in 1891 with the import of steam-powered tractor and rotary hoes. Since then the country has witnessed several milestones in the course of mechanization development. The focal plain agro-ecological zone of the state is the maximum and almost fully modernized area. As of now, there are two methods of practicing farming apparatus use: as a proprietor and/or through custom renting provision which coincides with Vietnam and Bangladesh. Historically, mechanization patterns in Vietnam can been described by tillage machinery with associated implement equipment use preceding 1975. This was non-linear, followed by a decreasing trend during the 80s prior to recovery during the 90s, with significant disparities in implementation status across the areas. In 2018, the number of tillage implements and harvesters was boosted about 1.6 and 25.6 times, respectively compared with 2006. The percentage of machinery use in soil tillage operation is $80 \%$ of the whole territory of cultivable land in Vietnam, compared to about 90\% in Bangladesh and 100\% in Thailand. Mechanization in Bangladesh started before independence with the importation of 2-wheel tractors and irrigation pumps in the last part of the 1960s as part of 'Green Revolution' activities. To continue this momentum, the Bangladesh Government permitted the continuation of agricultural machinery importation after later autonomy. Machinery use in different agricultural activities has increased in recent years in the areas of irrigation, land preparation, intercultural operation, and threshing. Though its degree of advancement is by and large still quite low contrasted with other South Asian nations, it is noticeable that the most recent two decades, the pace of mechanization has increased
\end{abstract}


rapidly with the increase of mechanical power use in farm activities. The use of farm machinery in rice cultivation has been the most amazing when contrasted with different crops in these three nations. A clear comparison has been given in the paper, which aims to help researchers and policymakers take necessary measures.

Keywords: agricultural mechanization; present status; future plan and limitations

\section{Background}

Farming modernization is the procedure by which different machineries and associated implements are used to increase labor productivity as well as boost up agricultural and food production [1]. It is an imperative contribution for seeding, transplanting, safeguarding, reaping, handling and including values which have been generally disregarded in Bangladesh [2]. It measures the proficiency and profitability of all contributors utilized in crop cultivation. Farming modernization for the most includes different contributors, for example, design and fabrication, right choice, dissemination, utilizing, fixing, upkeep of mechanical gadgets and frameworks in agrarian activities and their supervision in farm operation with seeds, manure, irrigation, labor, and season [3]. In this way, one of the most significant measures for any regional improvement of farming is the degree of agrarian modernization. Workable agrarian modernization helps to guarantee different processing activity, quality handling, advertising exercises and improvement of significant worth chain successfully too. The degree of agrarian modernization of a zone can be assessed as $\mathrm{kW}$ per unit area, unit area per tillage implement, number of tillage implements (2-wheel or 4-wheel tractors) per 1000 hectares of land, and so forth [4]. To solve anticipated future difficulties in cultivation, particularly in paddy, farm modernization by using an increasing number of justifiable moderate complexity technologies has recently been favored in Bangladesh. The Government of Bangladesh has already initiated many activities to increase the level of mechanization in Bangladesh [5]. That's why the present study tour in Thailand and Vietnam is important to boost Bangladesh's mechanization by acquiring knowledge about mechanization in the respective countries in terms of policy, strategy, implementation procedures and government assistance.

\section{Methodology}

The study visit allowed us to identify the challenges, barriers, supports, strategies and implantation procedures of mechanization in rice and other crops to bear in mind while aiming to collect best practices and success stories by group discussions, presentations and field visits in two countries, namely Thailand and Vietnam. The study tour was organized by the Ministry of Agriculture (MoA), Dhaka, in collaboration with Katesart University, Thailand and the Sub-Institute of Agricultural Mechanization specially the Southern Institute of Agricultural Engineering and Postharvest Technology (SIAEP), Ho Chi Min City, Vietnam and with the financial support from NATP-2, Bangladesh Agricultural Research Council (BARC) component and Year Round Fruits Production Project, Department of Agricultural Extension (DAE). Kernel Intl. Limited, Dhaka organized the tour.

Group members (Dr. Md. Ruhul Amin Talukder, Additional Secretary, MoA, Dhaka; Dr. Md. Azhar Ali, Director, Plant Quarantine Wing, DAE, Dhaka; Mr. Md. Nurul Islam, Deputy Director, Year Round Fruits Production For Nutrition Improvement Project, DAE, Dhaka; Dr. Md. Miaruddin, Director, Training and Communication, Bangladesh Agricultural Research Institute, Gazipur and Dr. Md. Anwar Hossen, Senior Scientific Officer, Bangladesh Rice Research Institute (BRRI), Gazipur, Bangladesh) of the visiting team under the leadership of the Ministry of Agriculture (MoA) Additional Secretary, were from different disciplines and focused on similar objectives with different assignments. Pre-structured questionnaires carefully prepared in advance were used considering the objectives of the tour. 


\section{Findings}

\subsection{General Status of Agriculture}

\subsubsection{Thailand Agriculture}

Farming is a significant area and remains the biggest source of work for Thai people [6]. Employment in this sector has been shrinking sharply, from 64\% in 1990 to $48.8 \%$ in 2000 and is currently 39.9\% [7]. Being one of the world's net agricultural exporters, Thailand (Figure 1) is one of the largest holding hosts, with 5.9 million farms on a 23.9 million ha farming area occupying $46.6 \%$ of the entire land territory [3]. More than $50 \%$ of the all-out agrarian land is used for rice, $21.5 \%$ for farm crops, and $21.2 \%$ for cash crops [8]. The five most important crops with respect to coverage and value are rice production (10.75 ha), maize (1.11 million ha), sugarcane (1.14 million ha), cassava (1.03 million ha) and soybean ( 0.16 million ha). Field crops taken together account for more than $60 \%$ of the agricultural GDP [9]. The artificial supply of water coverage area is confined and not uniformly spread all over the country. There are about $265,200 \mathrm{~km}^{2}$ of cultivable land of which $49,600 \mathrm{~km}^{2}$ use artificial water supplies [10]. Around, 75\% of paddy rice is produced in rain-fed regions and approximately $25 \%$ of rice is grown in artificially flooded fields. About $11.7 \%$ of the artificially supplied water paddy land is in the focal plain, split $6.4 \%, 5 \%$ and $1.4 \%$ between the northern, upper east and southern regions [11]. It was observed during the visits that organic and cooperative farming are some of the fastest-growing areas of agriculture because of consumer demand, higher value and better profits.

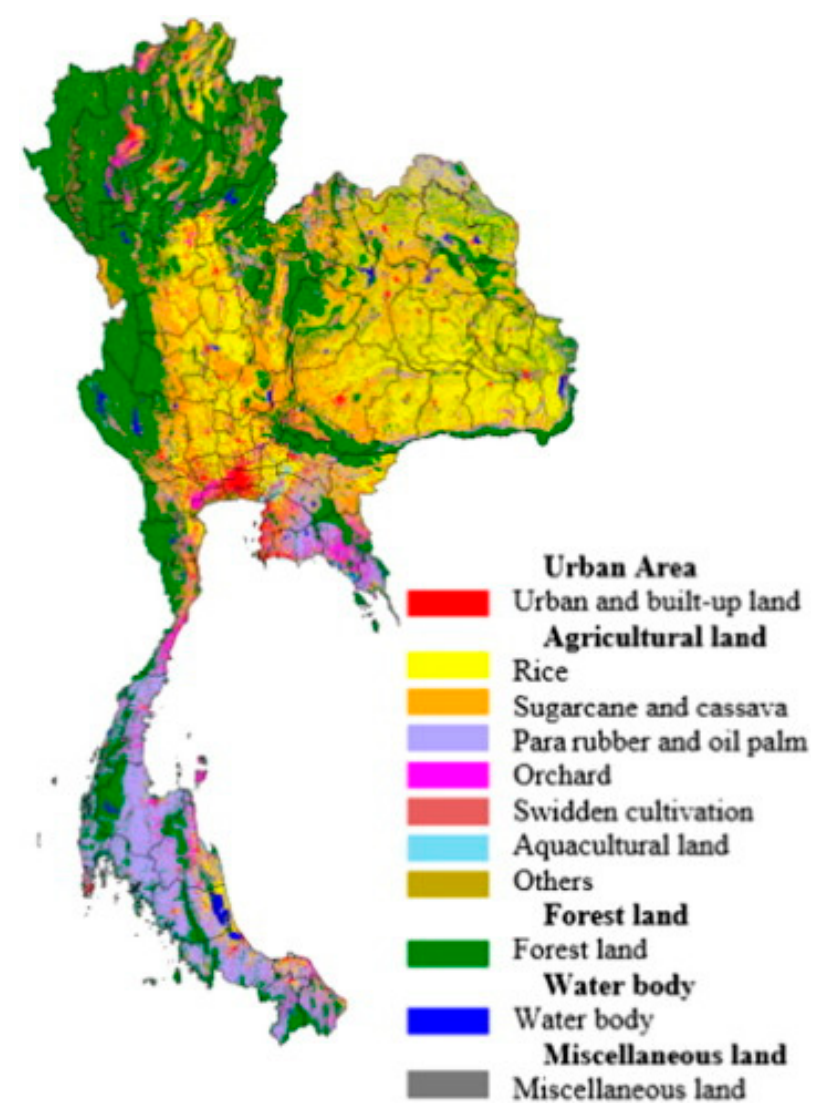

Figure 1. Agricultural regions in Thailand.

The agricultural sector contributes $10.5 \%$ of Thai GDP and this contribution has become relatively smaller over the last few years [3] (Table 1), however the overall trend seems to be increasing now. The average farm size slightly declined from 4.07 ha in 2010 to 4.04 ha/HH currently [9]. Agriculture 
no longer represent the major share of household income in Thailand, as farming contributes only around $28 \%$ of Thai households' income.

Therefore, the need to modernize farming by mechanizing its operation is unavoidable. The agricultural value added per worker in constant US $\$$ has increased from $\$ 645$ in 1990 to $\$ 1195$ in 2015 [12]. Only about one-third of households in the area are investing in agriculture; most are investing in mechanization.

Table 1. Comparison of GDP growth and contribution of different sectors [13].

\begin{tabular}{|c|c|c|c|c|c|c|c|c|c|}
\hline Countries & $\begin{array}{c}\text { GDP } \\
\text { Growth (\%) }\end{array}$ & $\begin{array}{l}\text { Agric to } \\
\text { GDP (\%) }\end{array}$ & $\begin{array}{c}\text { Industry to } \\
\text { GDP (\%) }\end{array}$ & $\begin{array}{c}\text { Net FDI } \\
\text { (million USD) }\end{array}$ & $\begin{array}{c}\text { Export/ } \\
\text { GDP (\%) }\end{array}$ & $\begin{array}{l}\text { Import/ } \\
\text { GDP (\%) }\end{array}$ & $\begin{array}{l}\text { Savings/ } \\
\text { GDP (\%) }\end{array}$ & $\begin{array}{l}\text { Rank } \\
\text { (EDB) }\end{array}$ & $\begin{array}{l}\text { Rank } \\
\text { (GCI) }\end{array}$ \\
\hline Thailand & 2.4 & 10.5 & 35.0 & 6316.0 & 59.7 & 50.6 & 31 & 21 & 40 \\
\hline Vietnam & 7.0 & 21.5 & 34.3 & $15,500.0$ & 107 & 103 & 23 & 70 & 67 \\
\hline Bangladesh & 8.2 & 14.23 & 28.5 & 1596.7 & 15.3 & 21.4 & 36 & 168 & 105 \\
\hline
\end{tabular}

\subsubsection{Vietnam Agriculture}

Vietnam is a country of Southeast Asia, bounded by the Pacific Ocean, China, Laos and Cambodia. The territory of Vietnam $329,560 \mathrm{~km}^{2}$; Populace 92.48 million, GDP by sector is divided into agrarian: $21.5 \%$, trade: $40.7 \%$; works: $37.7 \%$. The workforce is 49.18 million (Table 1 ). Manpower division by sector is farming: $48 \%$; trade: $21 \%$, administrations: $31 \%$ [14].

Agriculture development is blooming in Vietnam. Agribusiness is the mainstay of the nation's economy. The country can get two or three harvests within a 12-month growing season [15]. Rice is the most important crop. It is produced essentially in the Red and Mekong river deltas (Figure 2). Sugarcane, cassava, maize, yams, and nuts are also major crops in Vietnam following rice. Agriculture is highly labor-intensive in Vietnam [16].

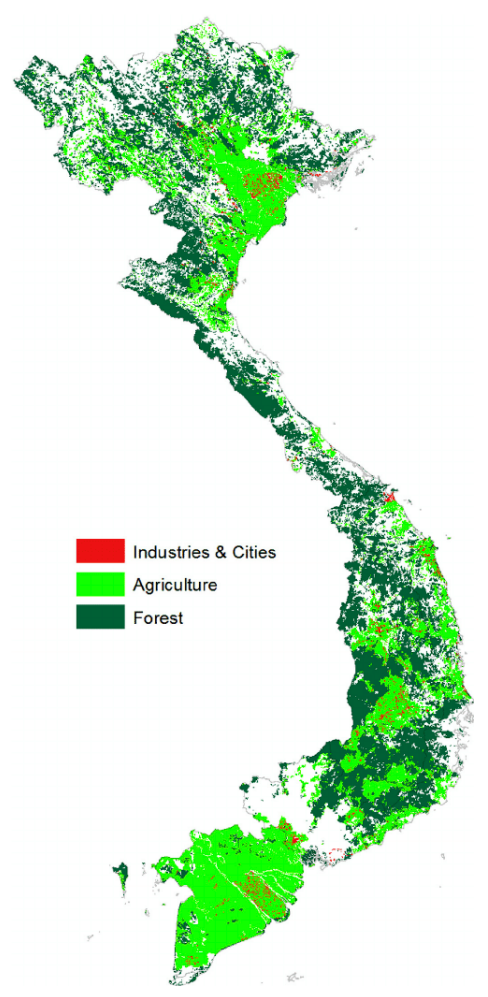

Figure 2. Agricultural regions in Vietnam. 
Vietnam is notable in more modest farm product exports like coffee, paddy, yarn, peanuts, sugarcane and tea. It ranks second for paddy in terms of trade, with $19.6 \%$ paddy area and $69 \%$ artificial flooded land. A minimum $30 \%$ of trading crops is cultivated all around the year [10]. Cassava and yams are also well-known exportable products cultivated in other parts of the nation. A few places even have fruit that is cultivated at specific times like bananas, jackfruit, oranges, mangoes and coconuts.

In spite of the fact that the country grows countless yields, the quality isn't sufficient. The more farming crops cultivated, the lower the value and Vietnam can't appear to get out of this endless loop. Farmers are needed as a result of this endless loop, and most of them don't have outside abilities after a profession in cultivating activities. Another strategy called the "inspiration" is established to help farmers and strategy authorities exploit economic globalization and dive further into the needs of the market. This could help stop the endless loop that is happening and developing agrarian activities.

\subsubsection{Bangladesh Agriculture}

Farming (Figure 3) is one of the most important areas in Bangladesh's economy (Table 1). The activities of this area is focused on work opportunity creation, reducing poverty, improvement of human resources, food safety and so forth. It adds $14.23 \%$ to the nation's GDP [17] and still occupies $41 \%$ of all the populace [8]. The estimated population of the country is about 162.7 million, of which $63.37 \%$ live in rural areas [8]. The total land is $14,570 \mathrm{~km}^{2}$, where $60 \%$ of the land is utilized for crop cultivation [18]. Production is still growing at a pace of $1.34 \%$ per year [19], though the cropland area is diminishing at the same time due to rapid urbanization and industrialization as well as the expansion of other human activities [20].

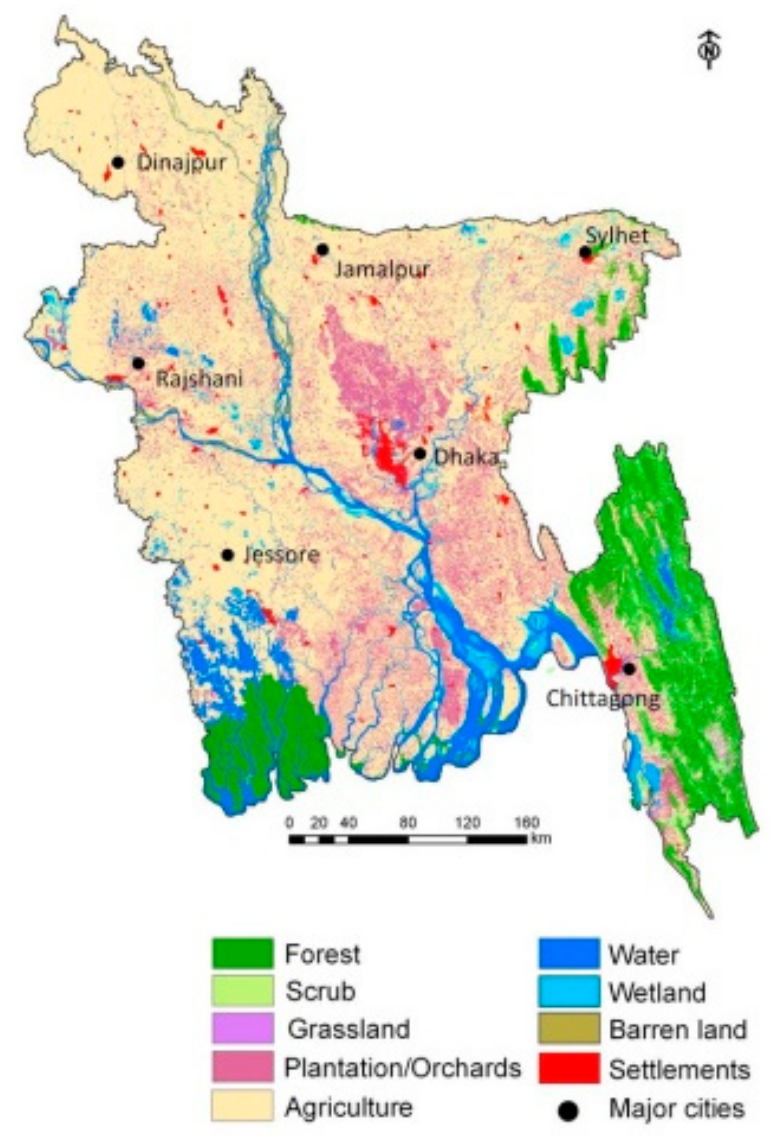

Figure 3. Agricultural regions in Bangladesh. 
Crop harvests in Bangladesh occur in three distinctive seasons, specifically Kharif-I (mid- March to mid-July), Kharif-II (mid-July to mid-October) and Rabi (mid-October to mid-March). The 'Kharif-I' period happens between summer and the monsoon season, 'Kharif-II' is the monsoon season and 'Rabi' is the summer season. Paddy rice is the prevailing harvest crop in three particular seasons, specifically, 'Aus' (March to June), 'Aman' (June to November) and 'Boro' (November to May). Wheat, oilseed crops, most pulses, potatoes and most of the vegetables are cultivated in Rabi season. Jute is cultivated as a Kharif-I crop and maize, chili, groundnut and mung bean are cultivated in both the Rabi and Kharif-I seasons [21]. Major cereals grains are rice, wheat, maize, grain, cheena (proso millet), kaon (millet), jowar (sorghum) and bajra (perals millet) [22].

In general the population meets its essential nutrition and mineral needs by consuming grain foods and more explicitly rice. The research organizations under the umbrella of the National Agricultural Research System (NARS), particularly BRRI, BARI, BINA and other associations, have created various high yielding grain crop cultivars and improved their cultivation. Paddy rice is the main cereal grain cultivated in this area from days of years. The contribution of paddy is about $92 \%$ of the all-out food grains cultivated in the nation and ranks fourth in the world. Approximately $77 \%$ of the cultivated area is covered by paddies and about 70\% of manpower is engaged in rice cultivation [23]. The contribution of paddy rice to GDP is $18 \%$. At present, paddy coverage is 11.42 million hectares of land and the harvest is about 33.6 million metric tons [24].

\subsection{Mechanization Status}

Agricultural mechanization refers to the use of modern technologies to mechanize agricultural activities, which enormously increases the efficiency of farm laborers. In present times, modern technologies have switched many farming activities done in the past by human or draft animal power. There are lots of examples of the use of simple devices such as diggers, shovels, ploughs, etc. in previous agricultural activities. However, the continuous combination of machines since the Industrial Revolution has permitted cultivation to require much less labor involvement everywhere in the world. Mechanization in Thailand and Vietnam is discussed below.

\subsubsection{Mechanization in Thailand}

Modern agriculture plays a vital role in Thailand, where land cultivation activities are quickly changing from agriculture land cultivation to an agribusiness model in the region's $46.6 \%$ absolute land distribution allocated to farming practices [9]. Agricultural mechanization in Thailand started in 1891 with the import of steam powered tractors and rotary hoes by the government. Since then the country has witnessed several mechanization development milestones. Currently mechanized agribusiness incorporates the utilization of modern tillage implements, reaping machinery, incalculable kinds of farm equipment as well as planes and helicopters (for aerial pesticide application at a research level), and different transportation facilities.

Modernization of rice cultivation has been the most amazing aspect in contrast with different other crops. The central plain is an almost full modernized agricultural area. Presently, there are two methods of using modern agricultural technologies: as a proprietor as well as through custom renting systems. There exists significant variability among the areas in Thailand regarding farming technology usage. The lack of manpower and the need to bring down cultivation costs in farming make modernization an inescapable fact in the present cultivation scene in Thailand.

The number of agricultural 4-wheel tractors $(4 \mathrm{WT})$ per 1000 ha of cultivable area in Thailand has expanded exponentially since the 1960s [25]. Normally there are over 50 farm vehicles (tillage implements) for every 1000 ha of cultivable area in Thailand [26]. There is however an impressive dissimilarity between the districts in Thailand as far as rural technology use is concerned.

For land preparation, power tillers, tractors and rotavators are commonly used. For crop upkeep, rucksack sprayers, power-operated sprayers, and high-level force pumps with flexible hoses are popularly utilized. For reaping paddy rice, Thai-developed modern reaping technology is mostly 
used in watered zones; whereas in rain-fed areas manual harvesting by sickle is still utilized. Where traditional reaping is still an occurrence, paddy threshers are employed.

The proportion of modern technology owners to modern technology renters depends on the machine availability, capacity, brand and price [27]. Small and inexpensive machines such as power tillers, water pumps, sprayers, etc. are usually owned by farmers. In the case of $4 \mathrm{~W}$ tillage implements and machine operated threshers, just $6.4 \%$ and $6 \%$ of all the equipment is currently owned by Thai farmers, the majority being acquired through custom rental services [28]. Moreover, in Thailand there is still a significant number of small/marginalized end users, having exceptionally little land consisting and/or potentially situated in distant/inaccessible non-urbanized areas, who cannot afford the custom rental services.

For mechanization, different regions require different mechanization solutions. Big, sophisticated and control-escalated technology such as reapers, transplanters, sowers and electric sprinklers are being used in the central plains of Thailand where farmers are more progressive and farm size is large [29]. However, there is still a lot of effort to modify/adjust these sophisticated/imported machines appropriately to adapt to local conditions. In the central zones and lower some portion of the northern area, 4-WT tillage implements of $30 \mathrm{KW}$ with rotating tillage implement are utilized rather than 2-WT tillage implements in paddy production. There is a labor deficiency problem during paddy and sugarcane reaping times in the plain zone. As a result, interest in suitable and productive paddy reapers has grown [30]. Nonetheless, the prerequisites for tillage implements, irrigation facility and machine operated threshers have not altered in the areas. On the other hand, the demand for power operated tillage implements has rapidly increased and Thai-developed paddies consolidate reapers in different areas.

On the contrary, in the North and Northeastern regions, farmers are relatively resource-poor and their farms are small. Farmers in these regions use labor intensive technology and manually operated sprayers. There are developing business sector for 4-WT tillage implements under $30 \mathrm{KW}$, alongside coordinating rotavators. These tractors are supplanting the current small tillage implements in the paddy cultivation frameworks of the central plain area and to a lower extent some portion of the northern areas.

Similarly, peasants are anticipating proper and effective reapers for paddy and sugarcane, as the acute shortage of labor during peak harvesting season results in losses both in terms of timeliness and in terms of total cost of harvesting.

Over the country, farm modernization has been shifting from heavy duty technology towards automation technology, for example, sowing technology, watering system frameworks, machineoperated dispenser, modern reaping technology, dryers utilizing biomass fuel, storehouses, fully automated rice mills and so on. In Thailand, most farming technologies are nationally developed, for example, tillage implements, 2-WT, seed sowers, circle harrows, irrigation equipment, different types of sprayers, winnowing technology, reaping technology, dryers, rice processing machines and so forth [29]. Rural apparatus (particularly water siphons, tillage implements and spare parts and mechanical sprayers) are basically imported from Japan, China and Malaysia while the significant customer nations for Thai farming machinery are Cambodia, Myanmar, Indonesia and Saudi Arabia [31].

\subsubsection{Mechanization in Vietnam}

The rapid increase of labor costs is likely a significant driver of agricultural modernization development. Actual labor pay rates grew comprehensively from 1992 to 1998 and stabilized from 1998 to 2004, likely mirroring the impacts of the Asian financial crisis of 1997/1998. From 2004 to 2008, the real labor price again quickly increased, at a rate much faster than seen during 1992-1998 [32]. Notwithstanding the quick development of agricultural modernization and its remarkable history in monetary and social construction, information on examples of development in farm modernization in Vietnam has been negligible. The verifiable development example of modernization in Vietnam had been non-straight, described to some degree by high soil tillage implement use preceding 1975 
followed by a decrease during the 80 s before recuperation during the 90 s, with extensive dissimilarities in reception patterns across the different regions of the country [33]. Since the financial and communal restructuring in the last part of the 80s, the non-public activities have quickly developed as the significant part in fulfilling the need for more prominent farm power use, including the household assembly and fabrication of 2-WT, the presentation of bigger size modern combined reapers and personal technology ownership rising as the essential providers of the rental system. Although the utilization of modern technology has progressively expanded from bigger farms to smaller farms, there are a few symbols that the similar points of interest have moved to bigger farm operations. Presently, farming modernization in Vietnam is expanding quickly. The number of soil tillage implements in 2018 expanded by 1.6-fold and the quantity of modern reapers expanded by 25.6-fold in contrast with 2006 [14]. The pace of modernization for land arrangement is $80 \%$ of the total cultivable farmland [34].

Typically, the input power per unit area of land rose from $1.6 \mathrm{hp}$ and for paddy $2.2 \mathrm{hp} / \mathrm{ha}$. The increasing trend of paddy land tillage modernization, paddy separators and modern reapers in the entire country are 95,50 and $50 \%$, respectively [31]. The number of dryers has reduced by $8 \%$, although the drying capacity has expanded by $20 \%$ in light of the fact that little dryers (1-4 tons/clump) have been supplanted by enormous profitable dryers (10-30 tons/cluster) in a step by step fashion [34]. There are in excess of 500,000 farm tillage implements, with existing limits of 6.5 million hp. Besides, there are around 900,000 farms machines of numerous types, for example, furrowers, hoe rotary, cultivators and cage wheels. What's more, there are 1500 reaper units, 600,237 paddy separator units with existing limits of $471,661 \mathrm{ton} / \mathrm{h}$, and 1,340,080 water siphoning machine units with an existing limit of $57,094,439 \mathrm{~m}^{3} / \mathrm{h}$ [35].

About $53 \%$ of farm tillage implements have a capacity $<12 \mathrm{hp}, 35 \%$ have $12-35 \mathrm{hp}$ and $12 \%$ have $>35$ hp capacity. Recently, the size of farm tillage implements has been expanding [36]. Farm tillage implements are for the most part utilized for modernized land management for crop establishment, for example, rice, corn and sugarcane.

Recently, the number of modern technologies utilized for farming operation purposes has rapidly increased. For instance, during 2018, the number of farm tillage implements increased by 1.6- fold in contrast with 2006, while the numbers of reapers expanded by 25.6-fold. Advanced modernization was principally concentrated in the Mekong River delta region that represents 75\% of the country's rural yield. Additionally, sprayers and plant shelter technology has expanded up to 5.8- fold and water siphons utilized in farming activities expanded by 1.2-fold. In spite of the fact the rate of increase of modernization in agribusiness remains restricted, Vietnam has increased the involvement with modernization in paddy cultivation by a great deal.

The nature of low scale technology, utilized for paddy cultivation is commonly acceptable, explicitly for reapers, paddy separator and dryers. Vietnamese agro-technology for paddy cultivation is practiced locally and delivered globally. Exploration and innovation in modernization in preservation agribusiness has been focused and is considering a strategy for copying in Vietnam. The ebb and flow of research is still reduced by locale and individual crops, for example, corn, soybeans, and so forth. Deep plowing without overturning, to both guarantee the depth and create underground channels to hold water when dry season is practiced.

\subsubsection{Mechanization in Bangladesh}

Mechanization started with the importation of power tillers and power pumps to accelerate the 'Green Revolution' accomplishments in the 1960s in what was then East Pakistan and continued after the independence of Bangladesh for modernizing agricultural tasks. Modern tillage and irrigation technology became familiar during this decade. In this period, the cooperative-based model of BARD in Cumilla promoted the service of 4WT [37] while BADC installed a significant number of deep irrigation wells in the DTW in the north area of the nation for supplying irrigation water free of cost which result was not a success [38]. All through the 60s, the ubiquity of LLP (Low Lift Pump) expanded with the expansion of reception of wet season rice variety (known as Boro season) in the low-slung 
areas of the nation. It is likewise noticed that the general water supply framework was manual and high yielding IRRI paddies were yet to be promoted in the nation.

During the 1970s, open venture was made in introducing deep irrigation schemes that expanded to about 9000 by 1978. During the 70s, BADC kept on working and dealt with a large quantity of deep tube wells and low lift irrigation schemes under their own management. However, in 1980, the tax on machinery imports was reduced to $15 \%$ and BADC quit leasing the low lift irrigation schemes under their own management and began retailing the new and old reconditioned low lift irrigation schemes to farmers [2]. In 1979, the administration chose to change its strategy of participation in the importation system and to denationalize the promotion of irrigation schemes and related equipment. Under this arrangement, BADC began to auction off existing and new low lift and deep irrigation schemes, at first to farmer cooperatives and later to single farmers [39].

The 1980s was the most significant period for farming modernization in the country. In 1981-82, BADC began donation of deep irrigation schemes dealing with sponsored costs with loans from business banks and the non-government division's import of low power diesel engines is prohibited in light of the drawdown of aquifers during the 1983 dry spell. President Ershad canceled certification prerequisites for imported technologies for farming operation in 1988 and explored the trade for importation of agrarian machines at an ostensible tax following an overwhelming flood that caused a loss of a huge amount of draft creature. This activity, joined with advertised progression and the reduction of taxes, brought about what could be named as a surge of low power engines and related cultivation, siphoning and others. Generally, during this decade, shallow tube-wells and tillage implements like 2-WT experienced a significant increase, and the number of shallow tube wells expanded from 93,000 out of 1982 to 260,000 out of 1990 with a 200\% expansion [40]. These changes likely contributed the most to quickening the modernization in Bangladesh and proceeded in the last decades. Importation of tillage implements/2WT was made obligation free, alongside loan support for acquisition of these technologies in 1995.

During the most recent two decades, a significant amount of the rural population has relocated to urban areas, searching for more lucrative jobs and a break from farm work. Cropping intensity increased from $153.74 \%$ in 1980 to 191\% in 2018 [41]. While research institutes have been developing and altering existing technologies, non-governmental agencies are engaged in adapting technologies imported principally from China and India.

For ease of understanding the comparative mechanization levels in Bangladesh, Thailand and Vietnam in percentages, trends of available power use in agriculture in $\mathrm{KW} / \mathrm{ha}$ and a comparative policy/strategy analysis in the context of mechanization are presented in tabulated form in Tables 2-4. 
Table 2. Status of farming activities modernization in Bangladesh, Thailand and Vietnam in percentages [2,13].

\begin{tabular}{|c|c|c|c|c|}
\hline \multirow{2}{*}{ Operation } & \multirow{2}{*}{ Methods } & \multicolumn{2}{|c|}{ Percentage $(\%)$} & \multirow[b]{2}{*}{ Vietnam } \\
\hline & & Bangladesh & Thailand & \\
\hline \multirow{2}{*}{ Land preparation } & $\begin{array}{l}\text { Tillage implements (2-WT and 3-WT, leveler, different type of } \\
\text { ploughs, tillage equipment, harrowers, etc.) }\end{array}$ & 98 & 100 & 98 (100 in the Mekong River Delta) \\
\hline & Cattle/traditional & 2 & 1 & \\
\hline \multirow{2}{*}{ Transplanting } & $\begin{array}{l}\text { Machine transplanting (transplanting machines, sowing } \\
\text { machines) }\end{array}$ & 5 & 80 & 30 (65 in the Mekong River Delta) \\
\hline & Human labor/conventional & 95 & 20 & \\
\hline \multirow{2}{*}{ Weeding } & $\begin{array}{l}\text { Engine power and human power operated equipment (power } \\
\text { weeders, manual weeders) }\end{array}$ & 8 & 20 & $<30$ \\
\hline & Manual & 92 & 80 & \\
\hline \multirow{2}{*}{ Fertilizer } & Machine operated (manual and power operated applicators) & 5 & 50 & \\
\hline & Human labor/conventional & 95 & 50 & \\
\hline Irrigation & & & & 85 \\
\hline \multirow{2}{*}{ Pesticide/Herbicide application } & Mechanical & 92 & 70 & 78 (86 in the Mekong River Delta \\
\hline & Manual & 8 & 30 & \\
\hline \multirow[t]{2}{*}{ Reaping } & $\begin{array}{l}\text { Self-operated, power tiller operated and modern combined } \\
\text { (PTO reapers, self-propelled reapers, combine harvesters, } \\
\text { reapers, trippers, stripper headers) }\end{array}$ & 7 & 90 & 57 (82 in the Mekong River Delta) \\
\hline & Conventional (sickle) & 93 & 10 & \\
\hline \multirow{2}{*}{ Threshing (paddy) } & Machine operated & 97 & 100 & 95 \\
\hline & Conventional & 3 & 0 & - \\
\hline \multirow[b]{2}{*}{ Post-harvest } & Mechanical (dryer) & 5 & 45 & 30 (39 in the Mekong River Delta) \\
\hline & Manual & 95 & - & - \\
\hline \multirow{3}{*}{ Processing } & Machine operated (de-husker, whitener, separator, polisher) & 42 & 90 & 95 (100\% in Mekong River Delta) \\
\hline & Mechanical (Engelburge) & 57 & 10 & 5 \\
\hline & Traditional & 1 & - & - \\
\hline \multirow{2}{*}{ Storage } & Modern & 15 & $>35$ & $<25$ \\
\hline & Traditional & 85 & - & - \\
\hline
\end{tabular}

Source: Hossen [2], class lectures in Thailand and Vietnam during 2019 visits by different governmental and non-governmental agricultural ogranizations. 
Table 3. Comparative trend of available power used in agriculture (kW/ha).

\begin{tabular}{cccc}
\hline Year & Bangladesh & Thailand & Vietnam \\
\hline 1980 & 0.38 & - & - \\
\hline 1990 & 0.40 & - & - \\
\hline 2000 & 0.81 & - & - \\
\hline 2010 & 1.4 & - & - \\
\hline 2018 & 1.82 & $\mathbf{2 . 3}$ & $\mathbf{1 . 8}$ \\
\hline
\end{tabular}

Source: Hossen [2], class lectures in Thailand and Vietnam during 2019 visits by different governmental and non-governmental agricultural ogranizations.

Table 4. Comparative policy/strategy analysis.

\begin{tabular}{|c|c|c|c|}
\hline Items & Bangladesh & Thailand & Vietnam \\
\hline Tillage implements/tiller & Imported whole machines & Only engines imported & Only engines imported \\
\hline Self-propelled reaper & $\begin{array}{l}\text { Both locally fabricated and } \\
\text { imported }\end{array}$ & Not used & $\begin{array}{l}\text { Import tractor and locally } \\
\text { fabricate }\end{array}$ \\
\hline Combine harvester & $\begin{array}{l}\text { Imported. Trying to develop } \\
\text { and fabricate locally }\end{array}$ & $\begin{array}{l}\text { Joint venture production } \\
\text { with Kubota Company }\end{array}$ & $\begin{array}{l}\text { Joint venture production with } \\
\text { Kubota Company, importation of } \\
\text { used machines from Japan }\end{array}$ \\
\hline $\begin{array}{l}\text { Power operated rice } \\
\text { transplanter }\end{array}$ & Imported & Imported & Imported and local fabrication \\
\hline Manual transplanter & Locally fabricate & Not used & Locally fabricated \\
\hline Spare parts & $\begin{array}{l}\text { Both locally fabricated and } \\
\text { imported }\end{array}$ & $\begin{array}{l}\text { Both locally fabricated } \\
\text { and imported }\end{array}$ & $\begin{array}{l}\text { Both locally fabricated and } \\
\text { imported }\end{array}$ \\
\hline Taxation on spare parts & $\begin{array}{l}\text { High tax on spare parts } \\
\quad(\text { about } 20 \text { to } 65 \%)\end{array}$ & $\begin{array}{l}\text { No tax on farming } \\
\text { technology and spare } \\
\text { parts }\end{array}$ & $\begin{array}{l}\text { Minimum tax on farming } \\
\text { technology and spare parts }\end{array}$ \\
\hline Taxation on whole machines & $\begin{array}{l}\text { Minimum tax on whole } \\
\text { agricultural machines } \\
\text { (5 to } 6.5 \%)\end{array}$ & No tax & $\begin{array}{c}\text { Minimum taxation on } \\
\text { agricultural machineryNo tax if } \\
\text { the machine is not yet fabricated } \\
\text { in Vietnam }\end{array}$ \\
\hline $\begin{array}{l}\text { Subsidy on interest rates of } \\
\text { loan for agricultural machinery } \\
\text { purchases }\end{array}$ & No subsidy & $\begin{array}{l}\text { Minimum interest rate } \\
\text { about } 4-6 \%\end{array}$ & $\begin{array}{l}\text { Zero interest on new and big } \\
\text { machines for new } \\
\text { entrepreneurship }\end{array}$ \\
\hline $\begin{array}{l}\text { Subsidy on machinery } \\
\text { purchase }\end{array}$ & Project base & No subsidy & $\begin{array}{l}\text { Project base. At present no } \\
\text { subsidy. }\end{array}$ \\
\hline $\begin{array}{l}\text { Graded materials produced in } \\
\text { the country }\end{array}$ & $\begin{array}{l}\text { Have steel mills but graded } \\
\text { material is not produced. }\end{array}$ & Produce and fabricate & $\begin{array}{l}\text { Imported. Have steel mills but } \\
\text { graded material is not produced. }\end{array}$ \\
\hline Govt. subsidy programs & Project subsidies, etc & $\begin{array}{l}\text { Training, demonstration, } \\
\text { R \& D, location-based } \\
\text { activities and } \\
\text { strengthening of local } \\
\text { entrepreneurship }\end{array}$ & $\begin{array}{c}\text { Training, demonstration, R \& D, } \\
\text { location-based activities and } \\
\text { strengthening of local } \\
\text { entrepreneurship }\end{array}$ \\
\hline $\begin{array}{l}\text { Training program for technical } \\
\text { manpower development }\end{array}$ & Not institutional form & Institutional form & Not institutional form \\
\hline
\end{tabular}

Source: Hossen [2], class lectures in Thailand and Vietnam during 2019 visits by different governmental and non-governmental agricultural ogranizations.

\subsection{Status of the Agricultural Machinery Industry in Thailand, Vietnam and Bangladesh}

\subsubsection{Thailand}

Currently, Thailand is capable of producing most of the machinery needed for its agricultural operations. Most of the farmers use locally manufactured machinery, such as 4-WT, power tillers, ploughs, harrows, irrigation pumps, sprayers, threshers, harvesters, modern harvesters, winnowing machinery, drying and milling technologies along with processing equipment, etc. Nevertheless, the technology locally developed by small or medium industries lacks standardization in value, durability and performance. Small quantities of specific/sophisticated technologies are obtained by 
Thai companies from overseas. As per a 2009 estimate by the Department of Industrial Work, there were 2809 local manufacturers of agricultural machinery registered in Thailand [42,43]. Some proprietors import new and used machinery from China, Japan, Korea and Europe.

\subsubsection{Vietnam}

The growth of the supply of power tillers in the domestic market during the 1990s was led by the growth in domestic manufacturing, although some power tillers had also been imported. By the end of the 1990s, 5000-6000 power tillers were already being domestically manufactured annually by major manufacturers like VIKYNO and VINAPRO, who were leading manufacturing of diesel engines and other machinery [44].

Currently, there are in excess of 500,000 4-WT and 2-WT, with existing capacities of 6.5 million hp of energy. Furthermore, there are around 900,000 farm technology units of numerous types, for example, furrowers, revolving diggers, cultivators and cage wheels. Moreover, there are 1500 reaper units, 600,237 paddy separator units with an existing limit of 471,661 ton/h, and 1,340,080 watering technology units with an existing limit $57,094,439 \mathrm{~m}^{3} / \mathrm{h}$. About $53 \%$ of farm tillage implements have limits under $12 \mathrm{hp}, 35 \%$ have 12 to $35 \mathrm{hp}$ and 12\% have a limit in excess of $35 \mathrm{hp}$ [45]. Right now, the size of farm tillage implements is expanding. Farm tillage implements are for the most part utilized for modernization of land management for crop cultivation.

Some power tillers were domestically manufactured using a diesel engine fitted onto a scrap chassis and Vietnam started exporting tractors (mostly power tillers). While there is no direct evidence, the importation of power tillers in the 1980s may have resulted in local adaptation and eventual manufacturing. For example, since the late 1980s, Daedong Industry Co. in Korea started exporting power tillers and farm engines to Vietnam via barter trade-gaining a foothold in communist countries. Similarly, Tongyang Moolsan Co. supplied power tillers and farm engines to Vietnam and was recognized by the Vietnamese government for its technology. Domestic manufacturing also accounts for 30 percent of combine-harvesters, which are mostly domestic production of Kubota combines by Kubota Vietnam Ltd. (the rest were often manufactured in China and exported to Vietnam) [45].

Rice milling machines are mainly manufactured in the country by companies such as Bui Van Ngo, Lamico, etc., with rice processing lines of 4- $40 \mathrm{ton} / \mathrm{hr}$ capacity, and grain dryer arrays of 30 to 200 ton per batch. Bui Van Ngo's product quality is considered world-class (comparable to Japanese Satake, which is one of the major suppliers of modern rice milling machines globally and Asia region) and Bui Van Ngo has exported rice equipment to about 20 countries in Asia, the Americas and Africa.

Manufacturing of engines in Vietnam has also grown. Today, diesel engines from 5 to $30 \mathrm{HP}$ can be produced domestically, with an annual production capacity of 40,000 units, approximately $30 \%$ of domestic market share. In addition, about 2000 provincial medium or small-size mechanical workshops deal with the fabrication, trial, sale and repair of machines. The leading manufacturer, Viet Nam Engine and Agricultural Machinery Corporation (VEAM), has also exported engines. VEAM is a large state-owned company and was recently converted into a Joint Stock entity in 2016. VEAM has seven large factories throughout Vietnam and has set up a national network of dealers for its 2WT, engines and other machinery. It inherits the old-time support for heavy industries and has some advantages over private companies in terms of loans and investment. However, to be competitive in the manufacturing of machines, the company should have a solid basis in modern metallurgy, which is severely lacking in Vietnam. Thus, even with a large inventory of machine-tools and production capacity, VEAM has just played a modest role in supplying machinery for agriculture.

\subsubsection{Bangladesh}

There are fifteen industries involved in fabricating and duplicating various numbers of privately designed technologies and various workshops associated with the current status of modernization. Some 40,000 metal workshops of different categories are working in delivering distinctive non-precision technology (weeders, harvesters and so on), providing necessary parts to support the repair of 
technologies in the nation [46]. Shippers of technologies have been trading the items either through their assigned outlets (4WT) or through broadly dispersed vendors and retailer organizes (2WT and diesel motors chiefly). It is noticed that local parts producer industries have been developing to create explicit spare pieces for 2 WT, 4 WT and for irrigation technologies. The National Agricultural Policy of 1999 accentuated to meet the deficiency of animal draft power by bringing in machines and crude materials to fabricate machines in a local level. In addition, tax relief, credit facilities for both the clients and dealers and the development of client gatherings/cooperatives for claiming or custom use of agrarian technologies were vital activities under this policy to help modernization. Be that as it may, this was not yet actualized completely.

\subsection{National Agricultural Machinery Plans}

\subsubsection{Thailand}

- The Twelfth National Plan (covering 2017-2021) aims to lessen production expenses and increment farmer incomes.

- The plan of action is to expand paddy cultivation to a vast area, with the expectation that the model will help reduce cultivation expenses, improving paddy quality and guaranteeing higher income for farmers.

- Besides, the intention is to establish technological rings which are gatherings of farmers and others associated with agribusiness. Technology rings will bolster this strategy with regular ventures and shared guidance of the oversight procedure of individual farms which should turn out to be more proficient and decrease cultivation costs.

\subsubsection{Vietnam}

- According to MARD, by the end of 2018, the level of agriculture mechanization (AM) in preparing the soil for annual crops (rice, sugarcane, corn, vegetables) reached about $94 \%$; the stage of rice sowing with sowing tools and transplanting reached $42 \%$; the stage of caring, spraying pesticides (rice, sugarcane, tea) reaches $77 \% ; 50 \%$ of the rice harvest ( $90 \%$ in the plain provinces). The growth rate of the number of machines and equipment in agricultural production increased by $2 \%$ compared to 2017.

- In the northern provinces, MARD has set a target to 2020 and orientations to 2030 for the stage of making rice land basically MA, shifting from using two-wheel tractors to four-wheeled tractors with high productivity and efficiency resulting in more favorable working conditions. Particularly in the Red River Delta, by 2020 the level of MA land preparation will reach 100\%, cultivation $70 \%$, and harvesting 90\%; in the North Central Coast and northern mountainous regions, the rice harvest stage reaches $50 \%$.

- With maize, AM stages sowing, tending and harvesting in flat production areas, concentrating AM from 70 to $80 \%$;

- With tea trees, in addition to tending, tilling the grass with machines, cutting and picking tea using machines more than $45 \%$

- For sugarcane, AM focuses on planting, tending, watering and especially harvesting, loading and handling of sugarcane leaves and tops after harvesting in concentrated production areas in the North Central Coast; the northern mountainous areas reach $50 \%$.

- In order to further promote agricultural production AM, MARD has set out a target to require specific development planning of machinery and equipment suitable to the conditions of each region, each type of crop and animal, especially in concentrated agricultural production areas, goods with advanced and modern machinery and equipment have high productivity, quality and efficiency, reducing agricultural losses; contributing to economic restructuring, labor, raising incomes for farmers and improving agricultural competitiveness. 
- The Vietnamese administration has recently executed new approaches to help farming modernization by presenting projects, for example, "Assemble New Rural". These program goals to develop new foundations to extend rustic and field roads. Users can now easily take soft loans from banks to put resources into farming technologies. There are various sorts of technologies and tillage implements under $30 \mathrm{hp}$ developed by Vietnamese industries, that can be effortlessly utilized by smallholders. In the following stages, the legislation will concentrate on mechanizing the entire procedure of creating and handling paddy rice, maize, sugarcane and peanuts.

\subsubsection{Bangladesh}

- The government of Bangladesh has published a farm modernization policy with the aim of expanding farm profitability by accelerating the popularization of simple yet efficient technologies at the grower level. The policy framework aims to reduce the production cost because of the lack of labor for development.

- The policy is planning to inspire the development of farmer-friendly technologies taking into account the small farm size, divided land proprietorship and types of soil. It is likewise focusing on incrementing cropping intensity with the view to increasing harvest yields. A farm modernization strategy would be instrumental to guarantee the quick development of agri-technologies and address the issues of lack of farm labor and low profitability.

- Nowadays, up to $98 \%$ of the farm area is plowed by 2-WT and 4-WT. Modern technologies are likewise utilized for $90 \%$ of pesticide application and $97 \%$ of threshing activity. The government has taken up a Tk 3198 core program undertaking to advance farm modernization, with an end goal to bail out farmers who experience the ill effects of the lack of farm workers during the crop harvesting collecting season. This is the first occasion when that the administration has incorporated a farm modernization venture into spending plans in Bangladesh.

- Farmers may obtain 50 to 70 percent impetus while purchasing agrarian technologies and furthermore simple bank loans, as the administration hopes to foment cultivation rotation.

- The Government of Bangladesh also detailed modernization guides for 2021, 2031 and 2041 in of 2016 [24]. The guide recognized the difficulties which hinder the farm modernization in Bangladesh.

- The challenges referenced in the guide were the expanding rate of the decrease of farm workers, decrease of farmland, environmental changes, land fracture, fabrication of substandard quality farming technologies, suitability of farm machinery for the local soil conditions, absence of farm roads, the significant cost of the farm technologies, the low buying intensity of farmers and reduction of ground water levels.

- The mechanization guide likewise urged the improvement stakeholders to be included effectively in accomplishing the modernization objective. The guide proposed the execution procedures to arrive at the objective of modernization development. The concerned authorities should find a way to accomplish the objectives.

- The government has placed an emphasis on an all-encompassing methodology through consideration of various partners, particularly government, non-government organizations, advancement collaborators, augmentation specialists, brokers, producers, elites, tax assessment offices, media stakeholders and so on. The administration is attempting to create a suitable environment to spread the modernization actions in quicker manner.

\subsection{Standardization}

\subsubsection{Thailand}

Thai Industrial Standard Institute (TISI, part of the Ministry of Industry, is answerable for certification of rural technologies. TISI was set up in 1968. It is the official authority with the mandate to improveme the Thai Industrial Standards (TIS), including agrarian technologies standards. 
Standardization of agrarian technologies has been established for power tillers, threshers, rice mills and combine harvesters, etc. However, the existing role in standardization has emphasized the standardization of parts for power tillers in order to reduce cost of manufacturing and spare parts. Standard transmission system (gear box) parts have been developed for use by local manufacturers.

\subsubsection{Vietnam}

Vietnam has national norms for the investigation and testing of technologies utilized in agrarian activities. The administration has approaches to assist the utilization of technologies in farming modernization. This has added to the fast increase in the utilization of rurally-developed technologies. In any case, the use of testing norms is as yet not necessary. The normalization framework comprises the National Standard TCVN (Technical Board of Vietnam) and principles at a crucial level. The TCVN is part of the Ministry of Science and Technology. Items guaranteed as reasonable to TCVN are given by the General Department for Standards and Quality following the Ministry of Science and Technology. Other certification centers don't give any endorsement of similarity for horticultural machines. Key norms are set up and delivered by every foundation. The foundations additionally perform testing and declare whether their items pass the crucial standards. By and large, the use of principles is still restricted and applied distinctly to a set number of machines.

\subsubsection{Bangladesh}

The 1980s was the most significant period for farming modernization in the country. President Hossain Md. Ershad nullified certification prerequisites of imported technologies in 1988 and opened the market for importation of these technologies (particularly power turners and siphons) at an ostensible duty following an overwhelming flood that caused an enormous loss of the stock of draft animals. This activity, cobmined with trading advancements and the reduction of duties, brought about what could be described as a surge in low power engine and related cultivation, irrigation and other technologiess. In 1987-89, non-government institute bans on low power engine imports were removed, import obligations are dispensed with, certification prerequisites for technologies were annulled, and irrigation wells exhaustion limitations were pulled back. Generally speaking, during this period, shallow and tillage implements (2-WT) saw a significant lift, the quantity of shallow tube wells expanded from 93,000 in 1982 to 260,000 in 1990 with a $200 \%$ development [23]. These changes presumably contributed the most to quickening the modernization of agricultural practices in Bangladesh and continued in the last decades. In 1995 the importation of small tillage implements (2WT) was made duty free, alongside credit support for the acquisition of these technologies. The current farming technologies and spare parts enterprises and workshops in the nation don't have certification quality control offices to guarantee the nature of items. There ought to be a typical office community in each significant rural technology territory and spare parts development either out in the open or by private industries' activities [47].

\subsection{Limitations to Mechanization}

\subsubsection{Thailand}

- In the past, the government didn't help the improvement of farmmodernization and still less up to this point. Present power utilization for farming activities is about $2.3 \mathrm{~kW} / \mathrm{ha}$.

- There is a lack of suitable technologcal advances for the use of machines at the farm level, just as a work in progress in the innovation for farming technologies.

- Collaboration based on government support is likewise insufficient. Users can't purchase modern farm machineries due to a lack of credit.

- Moreover, the cost for new technologies is high since they are mostly imported from abroad.

- The typical arable plot sizes is to small to operate such kind of machines for field activities. The contribution of relatives is less in farm practices which causes manpower shortages in farm 
work. Throughout the country, only 23.9 million hectares are arable land of which $68 \%$ is used for field crops. The country currently has 5.71 million farming households with four members per household on average. The average farm size is only 4 hectares per household [48].

- Custom renting was seen for above all else farm practices. In spite of the fact that farmers under downpours took care of agribusiness for paddy and sugarcane production possessed farm machines which were a bit much for their farm labor needs, they still needed to pay for the skilled help work. It had a significant impact on their yield.

\subsubsection{Vietnam}

- The level of modernization in farm activities is low and not uniform

- Compared with other countries in the region, the degree of penetration of more modern technologies in Vietnam is low, with an average of $1.8 \mathrm{~kW} / \mathrm{ha}$ of farmland.

- Low technical infrastructure and clematis cultivation practices that obstruct the utilization of modern equipment. Field size and shape in the nation is tiny and dispersed.

- At present, Vietnam has 70 million pieces of land, every family unit has on average just 0.7 ha of farmland, made up of 3-4 pieces of land. In spite of the fact that there is an arrangement of "combination of pieces of land", all in all in practice the land is as broken up as always. This constrains the implementation of modernization in the different stages of crop production.

- Vietnam's mechanical industry has not met the necessities of agrarian cultivation; interest in this unfamiliar field is still low.

- Agricultural items in Vietnam just meet the amount and nature of farm technology, for example, paddy cultivators, sugarcane harvesters, maize, little farm vehicles and so on.

- Additional foreign interest in the field of design and fabrication of agrarian technologies has been practically non-existent since 2009 when KUBOTA Vietnam Co., Ltd., started working in Vietnam.

\subsubsection{Bangladesh}

- The lack of skill manufacturers, operators and quality materials as well as high cost due to the numerous machines involved makes all activities expensive to operate. The power utilization pattern in agricultural cultivation is about $1.82 \mathrm{KW} / \mathrm{ha}$

- There is a lack of effective linkages among researchers, extension workers and users.

- Farmers can't handle the machines properly due to a lack of practical knowledge and maintenance costs are very high.

- Lack of purchase ability of the users, hindered by limited support for mechanization from the government, banks and private organizations.

- Lack of availability of spare parts, after-sales service, repair-maintenance facilities and hands on training. The very few trained personnel is not always available when machines break down.

- Fragmented land and unorganized farms at the rural level. The average size of owned land stood at 0.61 ha in 1988 and thus amount has declined significantly over time to peak at 0.48 ha in 2007 - a decline of $21 \%$ over the last two decades and has been followed by a further decrease to 0.39 ha in 2014 [38].

\subsection{Lessons Learned}

\subsubsection{Thailand}

- Extension centers work together with universities for the rapid dissemination of developed technology while university place an emphasis on both problem-oriented research based on farmers' demands and basic research 
- Thailand has emphasized agriculture-based industrialization. Expanding manufacturing activity throughout the country is prioritizing soil properties, land size, farmers' economic conditions and crops.

- Nowadays they are working on precision agriculture in parallel with mechatronic-based machinery research and development.

- They are giving priority to local level fabrication of machinery only importing engines and some critical parts.

- Enhancing the local manufacturing and fabrication capacity, there is no taxation on agricultural machinery and spare parts importation.

- Land size and soil type are suitable to promote large machinery for rice cultivation mechanization

- Hydrotillers with wider size wheels are used for marshy land tillage. This technology was developed based on the demands of the country

- Only a few different types of whole feed combine harvester are used for rice. Yanmar and Kubota branded transplanting and harvesting machines are used in Thailand.

- About $95 \%$ of the rice area is harvested by combine harvesters and $75 \%$ of these harvesters are made locally under joint-venture industries with Kubota.

- Rice transplanters are still being imported from Japan and Korea. Only at the research level are they trying to develop new machines. Rice is transplanted only in lowland areas (about $20 \%$ is transplanted) while in other areas, rice is broadcast using different types of seeder machine (about 80\%).

\subsubsection{Vietnam}

- The mechanization level is increasing rapidly in Vietnam due to the labor crisis and high labor wage rates as well as to improve the quality of grown crops.

- The percentage of mechanization varies depending on the crop, the production stage and regions.

- The mechanization rate of several stages is altogether high, but many machines are not appropriate, the level of equipment, technology and farming technique usage is still low and efficiency is not high.

- Mechanization of the harvest stages remains low and loss reduction is limited.

- Machines and equipment used in agriculture are more complex and diverse and the systems for maintenance and repair are undeveloped and the use efficiency is limited.

- Quality management of agricultural machinery has been be absent, market competition is not healthy and farmers lack information.

- On an average, every 100 farmer households have 1.05 large tractor (15 HP) and 2.4 small tractors.

- Every farm has four 4-wheel tractors; from five to six two-wheel tractors and one or two water pumps.

- Harvesting has a higher growth rate in Vietnam, from 5\% in 2000 to $42 \%$ in 2014, but there is the difference between the areas.

- Harvesting mechanization in the south-east region has reached around $70 \%$ while in the north the average was $40 \%$ in 2018.

- Capacity of drying rice at now reaches about $55 \%$, mainly with flat-bed static dryers that account for around $90 \%$, while tower dryers represent $10 \%$.

- In Vietnam, normally unparboiled rice is used while rice bran used as cattle feed and husks are used in the dryers as fuel.

- Planting of sugarcane by machine reaches $30 \%$ focused on several sugar companies in certain provinces (Quang Ngai, Tay Ninh, Dong Nai, Phu Yen).

- Several models of extension used sugarcane cutting machines in the form of spraying lines with a capacity of $0.1 \mathrm{cha} / \mathrm{h}$. 
- Corn mechanization for preparing the land and the work for caring for the crop in the plain-producing large regions is 70\% while shelling corn, picking and drying corn commodity, transportation and harvesting are mainly done manually.

- Mechanization for watering and caring for coffee-trees is around $80 \%$, For harvesting, the application of several harvesting machines with capacities of 1.2-2.0 ton of fruit/day is beginning, but there are not many yet, and the harvest is still mainly by hand.

- In the vegetables, flowers and fruit sector mechanization for preparing land and watering almost reaches $90 \%$. Around $60 \%$ use machines in the labors of care and plant protection. Harvesting is by hand.

- Several larger enterprises in Lam Dong, HCMC, Can Tho, and Dong Thap have purchased washing lines, cool storage and pack-houses for preliminary handling, preserving vegetables, flowers, fruits.

- Manufacture of machine and for agricultural production

For drying machines and tractors the production capacity is about 40,000 diesel engines/year, accounting for $40 \%$ of the market share in the country (mainly by Vietnam Engine Agricultural Machinery Corporation-VEAM-Ministry of Industry and Trade of the Socialist Republic of Vietnam).

- For combine harvesters there are 15 enterprises in the whole country, in which three enterprises including Tu Sang 2 in Tien Giang province, Phan Tan in Dong Thap and An Giang Engineering Co., Ltd. in An Giang have a capacity of 1000 machines/year.

- For rice mills over $90 \%$ are manufactured by Vietnam enterprises which have reached an advanced level (Bui Van Ngo Company, SINCO, LAMICO) and are exporting machinery to Southeast Asia, the Americas, and Africa

- $\quad$ KUBOTA Company in Vietnam

Design capacity is 15,000 tractors/year and 2000 combine harvesters/year

Work is focused on assembling tractors $(24-45 \mathrm{Hp})$, ground milling machines; combine harvesters (working width: 1.5-2 m); four/six-row potting machines and corn harvesting machines, making a huge contribution to the application and development of mechanization in Vietnam

\subsection{Conclusions}

Mechanization in agriculture is widespread on both irrigated and rain-fed croplands, for rice and field crops (sugarcane, cassava, maize), due to the scarcity and high cost of labor in both studied countries. Domestic fabrication of technologies began with in-country with innovations and popularization based on farmers' needs. Lightweight machines (2WT, small gatherers) have disseminated despite the fact that land size in Thailand and Vietnam is generally enormous contrasted with other Asian nations. Mechanization with large machinery like combine harvesters and tractors has been successes thanks to joint-venture production with Kubota. Smallholders have profited by using multipurpose machines or recruiting technologies. Modernization to a great extent is driven by non-governmental organizations, with the opportune sharing of plans and models by the governmental sector/research institutions. Thus research capacity building facilities need to be developed for sustainable mechanization in Bangladesh.

\subsection{Recommendations}

- Parallel to the importation of machinery, emphasis should be given to research and development.

- Location and soil condition-specific technology should be developed.

- Spare parts should be exempted from taxes to increase the local fabrication capacity. 
- Separate agricultural institutions need to be established for sustainable mechanization in agriculture.

- Universities, research organizations and extension agencies should work very closely and effectively address the present priorities.

- A significant number of zones from declared 100 economic zones should be formulated inclusively for agro-machinery and processing technology generation and fabrication.

- Joint venture companies need to be established like in Thailand and Vietnam for producing domestic transplanting and harvesting technologies.

Author Contributions: M.A.H. conceptualized and wrote the manuscript and provided data for Tables 1-3. M.R.A.T., M.M., M.A.A. and M.N.I. conducted interviews to collect information during the study tour in Thailand and Vietnam. M.R.A.M., H.R., S.P., and M.M.R. helped to collect the relevant review of the literature. All authors have read and agreed to the published version of the manuscript.

Funding: This research was funded by the projects "National Agricultural Technology Program-Phase-2 (NATP-2), Project Implementation Unit (PIU), Bangladesh Agricultural Research Council (BARC), Dhaka, Bangladesh and "Year Round Fruits Production Project" under Department of Agricultural Extension (DAE), Dhaka, Bangladesh.

Acknowledgments: On behalf of the Team, I would like to express our gratitude and sincere thanks to the Ministry of Agriculture, BRRI, BARI and DAE for selecting the Team members for the Study Tour to Vietnam and Thailand. The Team is also thankful to the authority of NATP-2, BARC component and Year Round Fruits Production Project, DAE for offering financial support. Special thanks and gratitude are due to Katesart University, Thailand, Southern Institute of Agricultural Engineering and Postharvest Technology (SIAEP), HO Chi Min City, and Kernel Intl Limited, Dhaka for organizing the tour and extending their cordial cooperation during the visit.

Conflicts of Interest: The authors declare no conflict of interest.

\section{References}

1. Anonymous. Agricultural Mechanization and Machinery Management: Mechanization Management under Agricultural Machinery Management \& Maintenance. 2016. Available online: https://www.coursehero.com/ file/18919584/EBE-2507-Mechanization-Management-revised-10th-Juky-2016/ (accessed on 14 August 2020).

2. Hossen, M.A. Mechanization in Bangladesh: Way of Modernization in Agriculture Int. J. Eng. Trends Technol. 2019, 67, 69-77. [CrossRef]

3. World Food and Agricullture (FAO). Statistical Pocket Book 2018; Food and Agriculture Organization of the United Nations: Rome, Italy, 2018.

4. Singh, G. Estimation of mechanization index and its impact on production and economic factors-a case study in India. J. Biosyst. Eng. 2006, 93, 99-106. [CrossRef]

5. Implementation Monitoring and Evaluation Division (IMED). Impact Evaluation of Enhancement of Agricultural Production and Rural Employment through Extension of Agricultural Engineering Technologies (2nd Revised). 2014. Available online: https://imed.portal.gov.bd/sites/default/files/files/imed.portal.gov.bd/ page/e773d5bf_182e_4fc5_a856_dfd3c8d05ced/enhancement_agri.pdf (accessed on 21 August 2020).

6. Soni, P. Agricultural Mechanization in Thailand: Current Status and Future Outlook. Agric. Mech. Asia Afr. Lat. Am. 2016, 47, 58-66.

7. Singhapreecha, C. Economy and Agriculture in Thailand: Overview of Agricultural Policy. Paper published FFTC-AP, Food and Fertilizer Technology for the Asia and Pacific Region. 2014. Available online: https: //ap.fftc.org.tw/article/682 (accessed on 16 September 2020).

8. Mrema, G.; Soni, C.P.; Rolle, R. A Regional Strategy for Sustainable Agricultural Mechanization: Sustainable Mechanization across Agri-Food Supply Chains in Asia and the Pacific Region; FAO of the United Nations, Regional Office for Asia and the Pacific (FAO-RAP): Bangkok, Thailand, 2014; Available online: www.fao. org/publications (accessed on 16 September 2020).

9. OAE. Agricultural Statistics 2015 Yearbook; Office of the Agricultural Economics, Ministry of Agriculture and Cooperative: Bangkok, Thailand, 2015.

10. Apipattanavis, S.; Ketpratoom, S.; Kladkempetch, P. Water Management in Thailand. Irrig. Drain. 2008, 67, 113-117. [CrossRef] 
11. Soni, P.; Ou, Y. Agricultural Mechanization at a Glance Selected Country Studies in Asia on Agricultural Machinery Development, Publisher: UN-ESCAP/UN-APCAEM. January 2010. Available online: https://www.researchgate.net/figure/Economically-active-population-in-agriculture-as-a-percentof-total-economically-active_fig3_320014183 (accessed on 14 August 2019).

12. World Food and Agriculture (FAO). Statistical Pocketbook 2015; Food and Agriculture Organization of the United Nations: Rome, Italy, 2015.

13. Talukdar, M.R.; Khan, M.A.A.; Hossen, M.A.; Islam, M.N.; Uddin, M.M.; Comparative Agricultural and Export Market Development in Thailand and Vietnam: A Policy Paper Presented in the Ministry of Agriculture (MoA). 27 August 2020. Available online: https://moa.gov.bd/ (accessed on 16 September 2020).

14. Tien, L.Q. Constraints and challenges to adoption and promotion of CA and CA mechanization in Viet Nam. In Proceedings of the Regional Workshop on the Role of Mechanization in Strengthening Smallholders' Resilience through Conservation Agriculture in Asia and the Pacific, Phnom Penh, Cambodia, 18-20 April 2018; Available online: http://www.un-csam.org/ppta/201804CA/19/6.\%20PPT_CA\%20Workshop_Vietnam. pdf (accessed on 14 August 2019).

15. Anonymous. Agriculture in Vietnam: On the Road to Development, Borgenproject.org. 2019. Available online: https://borgenproject.org/agriculture-in-vietnam/ (accessed on 10 September 2020).

16. GSO. Statistical Yearbook of Vietnam 2017; Statistical Publishing House: Hanoi, Vietnam, 2018.

17. Bangladesh Economic Review (BER). Finance Division, Ministry of Finance, Government of Peoples' Republic of Bangladesh; Bangladesh Bureau of Statistics, Finance Division, Bangladesh Bank, Ministry of Health and Family Welfare, SEC: Dhaka, Bangladesh, 2010.

18. Statistical Yearbook of Bangladesh; Bangladesh Bureau of Statistics (BBS): Dhaka, Bangladesh, 2016.

19. Statistical Yearbook of Bangladesh; Bangladesh Bureau of Statistics (BBS): Dhaka, Bangladesh, 2018.

20. Ahmed, S. Food and Agriculture in Bangladesh. In Encyclopedia of Food and Agricultural Ethics; Springer: Dordrecht, The Netherlands, 2013; pp. 1-8. ISBN 978-94-007-6167-4. [CrossRef]

21. Chowdhury, M.A.H.; Hassan, M.S. Hand Book of Agricultural Technology; Bangladesh Agricultural Research Council: Farmgate, Dhaka, 2013; p. 230. Available online: http://btri.portal.gov.bd/sites/default/files/files/ btri.portal.gov.bd/page/a556434c_e9c9_4269_9f4e_df75d712604d/Hand\%20Book\%20of\%20Agricultural\% 20Technology.pdf (accessed on 14 August 2020).

22. Banglapedia. Crops: National Encyclopedia of Bangladesh. 2015. Available online: http://en.banglapedia. org/index.php?title=Cereal (accessed on 16 September 2020).

23. Tilman, D.; Balzer, C.; Hill, J.; Befort, B.L. Global food demand and the sustainable intensification of agriculture. Proc. Natl. Acad. Sci. USA 2011, 108, 20260-20264. [PubMed]

24. MoA. Mechanization Road Map 2021, 2031 and 2041 of Bangladesh. 2016. Available online: www.moa.gov.bd (accessed on 12 July 2019).

25. World Bank (WB). Annual Report; World Bank Group: Washington, DC, USA, 2015; Available online: http://documents.worldbank.org/curated/en/880681467998200702/World-Bank-annual-report-2015 (accessed on 12 July 2019).

26. FAOSTAT. Statistical Data-Base; Food and Agriculture Or-ganization of the United Nations: Rome, Italy, 2016.

27. UNAPCAEM Country Report-Myanmar. Agricultural Mechanization Status and Context in Myanmar. In Proceedings of the UNAPCAEM-FAO Roundtable on SustainableAgricultural Mechanization Strategies in Asia, Bangkok, Thailand, 8-9 December 2011.

28. Thepent, V. Country Presentation Paper Thailand. In Proceedings of the 2th Regional Forum on Sustainable Agricultural Mechanization Environment for Custom Hiring of Agricultural Machinery, Agricultural Engineering Research Institute (AERI), Department of Agriculture (DOA), Ministry of Agricultural and Cooperative (MOAC), Serpong, Indonesia, 9-11 September 2014.

29. Nalavade, P.; Soni, P.; Salokhe, V.M.; Niyamapa, T. Develop-ment of a Powered Disc Harrow for on-farm Crop Residue Man-agement. Int. Agric. Eng. J. 2013, 22, 49-60.

30. Thepent, V. Agricultural Mechanization in Thailand. In Proceedings of the 16th TSAE National Conference and the 8th TSAE International Conference. Faculty of Engineering at Kamphaeng Saen Kasetsart University, Kamphaeng Saen, Thailand, 17-19 March 2015. 
31. Tuan, T.D. Policy brief on Status of Agricultural Mechanization and Testing in Vietnam, Published by ESCAP, CSAM. 2016. Available online: http://www.un-csam.org/Publication/PB201601.pdf (accessed on 16 September 2020).

32. Liu, Y.; Violette, W.; Barrett, C.B. Structural Transformation and Intertemporal Evolution of Real Wages, Machine Use, and -Farm Size-Productivity Relationships in Vietnam, this Paper Prepared Undertaken as a Part of, and Partially Funded by, Bill and Melinda Gates Foundation and the CGIAR Research Program on Policies, Institutions, and Markets (PIM) led by IFPRI. 2017. Available online: http://barrett.dyson.cornell. edu/files/papers/Vietnam-fp-final.pdf (accessed on 12 July 2019).

33. Take-home, H.; Liu, Y.; van Nguyen, C.; Masias, I. Evolution of Agricultural Mechanization in Vietnam: Insights from a Literature Review and Multiple Rounds of a Farm Household Survey; IFPRI Discussion Paper 1724. International Food Policy Research Institute (IFPRI): Washington, DC, USA, 2018; Available online: http://ebrary.ifpri.org/cdm/ref/collection/p15738coll2/id/132559 (accessed on 12 July 2019).

34. Center for Sustainable Agricultural Mechanization (CSAM). Policy brief: Status of Agricultural Mechanization and Testing in Vietnam. 2019. Available online: http://www.un-csam.org/Publication/PB201601.pdf (accessed on 16 September 2020).

35. Viet, N.G. Current Status of Agricultural Mechanization in Vietnam, Director of Dept. of Science, Training and International Cooperation; Vietnam Institute of Agricultural Engineering and Post-Harvest Technology (VIAEP): Hanoi, Vietnam, 2012.

36. Haque, M.E.; Bell, R.W.; Kassam, A.; Mia, M.N.N. Versatile Strip Seed Drill: A 2-Wheel Tractor-Based Option for Smallholders to Implement Conservation Agriculture in Asia and Africa. Environments 2016, 3, 1-13. [CrossRef]

37. Ou, Y.G.; Yang, D.T.; Yu, P.X.; Wang, Y.; Xli, B.X.; Zhang, Y.L. Experience and analysis on sugarcane mechanization at a state farm in China. In Proceedings of the 2002 ASAE Annual International Meeting/CIGRXVth World Congress. Hyatt Regency Chicago, Chicago, IL, USA, 28-31 July 2002.

38. Index Mundi. A Data Portal that Gathers Facts and Statistics from Multiple Sources and Turns Them into Easy to Use Visuals. 2017. Available online: https://www.indexmundi.com/facts/bangladesh/arable-land (accessed on 12 July 2019).

39. Hossain, M. The Impact of Shallow Tube-Wells and Boro Rice on Food Security in Bangladesh; IFPRI Discussion Paper 00917; International Food Policy Research Institute (IFPRI): Washington, DC, USA, 2009; Available online: https://www.ifpri.org/publication/impact-shallow-tubewells-and-boro-rice-foodsecurity-bangladesh (accessed on 12 July 2019).

40. Kabir, M.S.; Salam, M.U.; Chowdhury, A.; Rahman, N.M.E.; Iftekharuddaula, K.M.; Rahman, S.M.; Rashid, M.H.; Dipti, S.S.; Islam, A.; Latif, M.A.; et al. Rice Vision for Bangladesh: 2050 and Beyond. Bangladesh Rice J. 2015, 19, 1-18.

41. Parvin, N.; Khatun, A.; Quais, M.; Nasim, M. Cropping Pattern, Intensity and Diversity in Dhaka Region. Bangladesh Rice J. 2018, 21, 123-141. [CrossRef]

42. CSAM. Country Reports from Asia Pacific Countries on Current Status of Agricultural Mechanization as Presented to the CSAM/ANTAM Consultations of 2014, ESCAP, CSAM, A-7/F; CSAM: Beijing, China, 2014; Available online: http://un-csam.org/publication/ANTAM2015.pdf (accessed on 12 July 2019).

43. Thepent, V. Country Report on Sustainable Agricultural Mechanization in Thailand. In Proceedings of the Regional Forum of the UN-CSAM on Sustainable Agricultural Mechanization in Asia and the Pacific, Qingdao, China, 26-27 October 2013.

44. JICA. Vietnam: Report by Agricultural Development Survey Team; JICA: Tokyo, Japan, 2000.

45. MIT. Vietnam Manufacturing Supporting Industry Yearbook 2014-2015, SIDEC, Institute of Industrial Policy and Strategies, Ministry of Industry and Trade; MIT: Hanoi, Vietnam, 2015.

46. Ziauddin, A.T.M.; Ahmed, H. Research Priorities in Farm Machinery, Irrigation E Water Management and Post-Harvest Technology (Engineering Aspects), Agricultural Research Priority: Vision-2030 and Beyond; Bangladesh Agricultural Research Council: Farmgate, Dhaka, 2010. 
47. Alam, M.; Khan, I.N. Agricultural Mechanization: Status, Challenges and Opportunities in Bangladesh. In Mechanization for Sustainable Agricultural Intensification in SAARC Region; Gurung, T.R., Kabir, W., Bokhtiar, S.M., Eds.; SAARC Agriculture Centre: Dhaka, Bangladesh, 2017; p. 4170.

48. World Food and Agriculture (FAO). Family Farming Knowledge Platform of Thailand. 2020. Available online: http://www.fao.org/family-farming/countries/tha/en/ (accessed on 16 September 2020).

(C) 2020 by the authors. Licensee MDPI, Basel, Switzerland. This article is an open access article distributed under the terms and conditions of the Creative Commons Attribution (CC BY) license (http://creativecommons.org/licenses/by/4.0/). 